\title{
The Relationship between e-Commerce Adoption and Competition in the Hotel Industry
}

\author{
Nomsa Mndzebele
}

\begin{abstract}
E-commerce is growing up very fast over the world and has tremendous potential for creating business opportunities. This paper examines if there is a relationship between competition and the extent of Electronic Commerce adoption in B2B inbound communication, B2C order taking, B2B outbound communication and B2B inbound communication. A quantitative methodology approach was adopted. The findings show a mean of 3.29. The study also found that there is a correlation between competition and e-commerce. Data was collected in $\mathbf{3 3 2}$ hotels in seven provinces in South Africa. The data collected was analysed using correlation and multiple regression analysis.
\end{abstract}

Index Terms - Competition, adoption, electronic commerce.

\section{INTRODUCTION}

Competition can be defined as "the degree that the company is affected by competitors in the market" [1]. The Hotel industry is a highly competitive business. The competitiveness of an industry and the method by which a firm competes has a considerable effect on the firms Information Technology performance. The intensity of competition amongst hotels within the same location can affect the decision of those hotels to either adopt or ignore new technologies [2]. Business strategies are to maintain their competitiveness in order to avoid being replaced [3]. [4] states that the hotel industry is a very competitive one, if hotels do not access information on time and customers are delayed the customers will take patronage to another hotel. Because guests are becoming more demanding than before, hotels have to stay competitive in today's market and have to improve their operational efficiency which can be done by upgrading and updating to new technologies. Hotels that quickly adopt improved Information Technology systems are less likely to lose potential customers to other hotels that offer better facilities. Hotels that are relatively new are much more interested than older hotels in adopting new technologies, such as e-checkout [5].

There is a worldwide appreciation for the function played by technology in improving the hotels competitive edge. In order to succeed hoteliers need to think more like retailers. Hoteliers have to realize how important it is to meet the customers' expectations, they cannot afford to think of customers as "heads" and "beds" [6]. The belief that innovation is a basis for competitive gain will fuel the propensity of a firm to adopt new technologies.

Manuscript received October 5, 2014; revised December 6, 2014.

Nomsa Mndzebele is with the Business Administration Department, Faculty of Commerce, University of Swaziland, Kwaluseni, Swaziland (e-mail: nomsa@uniswa.sz).
During the apartheid era in South Africa, the local hotels flourished because of lack of competition. Today a number of the international hoteliers have invested in South African market and the hotels in South Africa have had to expand because of competition [7]. In South Africa, Electronic Commerce (EC) represents a chance for the country to catch up with the current pressure of globalization and its related challenges and also connect with global markets. As a result of information technology, hotels have changed the way they manage business. EC has introduced forces and innovative competitors have, at the same time, created new opportunities for hotels.

Today Information Technology is considered as an essential tool in improving and enhancing the competitiveness of the economy of developed and developing countries [8]. Ref. [9] has examined the impact of competitive pressure on the application of internet based systems aimed at competitive advantage. Other researchers [10] have seen competitive pressure as being a significant determinant of a firm's level of computerization, adoption and utilization of inter-organizational [11]. Hotels have to change to avoid from being left behind in technology and how information systems and technology support business processes, decision making and competitive advantages [12]. If EC is used properly it should gain an advantage over competitors by reducing operational costs below that of others in the same industry. Therefore this paper discusses EC usage and competitive advantage in the hotel industry.

E-commerce is growing up very fast over the world and has become an important issue in many studies. Therefore, EC cannot be excluded as this technology has a huge impact in the hotel industry. EC has become more important to support an e-market system because it has opened new relations in electronic trade without restraint boundaries can be reached anywhere by any anyone [12]. The use of EC for marketing hotel services by hotel management companies is becoming increasingly popular around the globe [13]. By providing an affordable platform to differentiate their product from that of competitors, ICT plays a critical role in the competitiveness of tourism organization [14]. Studies [15] on communication technology, especially EC, have shown that, in order to compete in the marketplace, a firm has to utilize technology.

The hotels that were the first to set up EC have gained relatively greater benefits [16]. They also found that long-standing hotels have often attained a considerable standing amongst their customers and therefore do not see the need to adopt new technologies to expand their market share. However, [17] states that, hotels that have been in existence for some time find that new technology encourages new customers and they are able to increase their market share. While [18] claim that hotels that have been in existence for 
some time are less likely to adopt the latest technologies. Ref. [19] contends that firms that adopt EC may alter the rules of the competition, affect the industry's structure and come up with new ways of outperforming rivals. Therefore competition is likely to drive firms to initiate and adopt EC in order to gain and maintain a competitive edge.

The extent to which EC has been adopted and used in other sectors has attracted the attention of the tourism industry. Adoption and usage of EC in developed countries has produced tremendous results with revenues in the travel and tourism industry. In Malaysia EC market size was RM1.8 billion in 2010 estimated to increase RM5 billion in 2014 . Although there is an increase it is still considered slow and the lowest among Asian countries [20]. The adoption and use of EC by the tourism industry has not been uniform, but rather it has varied in different countries and among different businesses. EC could help achieve the potential of the African tourism industry thus increasing the in-flow of the much-needed foreign currency into their economy. E-commerce can enhance ones competitiveness, offer better access to markets, provide increased business opportunities and contribute towards economic growth. Developing countries have a problem of lack of knowledge on how to develop a competitive edge and how to invest in EC so that they can benefit from it [21].

\section{Methodology}

The study was conducted through a questionnaire survey amongst hotels that had been sampled using a correlational and descriptive research survey. The descriptive design was chosen because it examines the present status and the extent of adoption of EC within the South African hotel industry. The target population was hotel managers because they make final decision on capital expenditure.

400 hotels were drawn from a database of three major groups [22] suggested by the South African Tourism Office [23]. From each of the three groups, systematic sampling method was done so that each group would be represented. A pilot study was done of eight hotel managers that had not been sampled. After the pilot study it is then that the 400 questionnaires were emailed to the respondents and reminders were sent out. 26 questionnaires were returned after the reminders had been sent out and the remaining questionnaires were self-administered and the researcher was able to get 306. Total questionnaire collected from the hotels was 332. The items chosen in this study met the acceptable standards at reliability analyses and Cronbanch alpha was said to be 0.91 . A 5-iterm likert scale ranging from "strongly disagree" (1) to "strongly agree" (5) using to measure all items used in the questionnaires were used. The hotels selected were in nine provinces but data (332 questionnaires) was collected in seven provinces, Western Cape, Gauteng, KwaZulu-Natal, Mpumalanga, Limpopo, Free State and Eastern Cape.

Purpose of the study was to find out if there is a relationship between competition and the extent of EC adoption. To answer the research questions, the questionnaires were dived into competition and the degree of adoption of EC which includes EC acceptance of B2C outbound communication, $\mathrm{B} 2 \mathrm{C}$ order taking, $\mathrm{B} 2 \mathrm{~B}$ inbound communication and $\mathrm{B} 2 \mathrm{~B}$ outbound communication. Spearmen's correlations were used to assess the relationship between the independent variable (competition) and the dependent variable (B2C outbound communication, B2C order taking, B2B inbound communication and $\mathrm{B} 2 \mathrm{~B}$ outbound communication).

From the literature reviewed the researcher identified competition as one of the determinants of EC adoption by hotels in South Africa. Ref. [24] found that if competition is high on a firm, then the hotel is more likely to adopt EC. Ref. [24] also found that competition had a strong positive relationship with EC adoption, thus the high level of competition, rivalry amongst the hotels led to higher EC adoption.

\section{FINDINGS}

From the questionnaire used to measure the relationship between competition and the extent of EC adoption, a mean score of 3.293 was reached which indicates that the managers of the hotels agree that the industry is a competitive one. This indicates that the hotel managers are engaged in intense professional rivalry.

TABLE I: SUMMARY OF THE SOME THE QUESTIONS ON THE ASSOCIATION BETWEEN A HOTEL HAVING ITS OWN INTERNET CONNECTION AND COMPETITION

\begin{tabular}{|c|c|c|c|c|}
\hline Questions & $\begin{array}{l}\text { B2C } \\
\text { (1) }\end{array}$ & $\begin{array}{l}\text { B2C } \\
(2)\end{array}$ & $\begin{array}{l}\text { B2B } \\
\text { (3) }\end{array}$ & $\begin{array}{l}\text { B2B } \\
(4)\end{array}$ \\
\hline & $P$ value & $P$ value & $P$ value & $\begin{array}{l}\mathbf{P} \\
\text { value }\end{array}$ \\
\hline Q.2: Pressure from buyers & & 0.002 & & 0.05 \\
\hline $\begin{array}{l}\text { Q.4:Vendors } \quad \text { actively } \\
\text { marketing EC }\end{array}$ & & & 0.000 & \\
\hline Q.5: Rivalry in the business & & & 0.000 & \\
\hline $\begin{array}{l}\text { Q.6: Customers switching to } \\
\text { a competitor }\end{array}$ & & 0.000 & & 0.04 \\
\hline
\end{tabular}

(1) B2C outbound communication (2) Order taking (3) B2B inbound competition (4) outbound competition

With regard to question 2 in Table I: .It was statistically significant that there is pressure from buyers to use EC because if a hotel does not use EC its customers will switch to other hotels, as the hotel industry is a competitive one. In $\mathrm{B} 2 \mathrm{~B}$ outbound there is pressure as well from suppliers to the hotels to use EC as suppliers do not like customers who will be using a manual system when there is an easier method of working. Hotels that increase their customer satisfaction through website information and high quality product provision will have a significantly positive influence on their customers [25]. Hotels have to address the customers' needs if they want to stay in business.

With regard to question 4 in Table I i.e. those hotels should consider EC adoption because vendors are marketing EC and if a hotel is not using EC it will be left behind therefore managers have to develop a positive attitude towards technology. These managers have to be careful because they might buy outdated systems if they are not up to date with what is being sold in the market [26].

With regard to question 5 in Table I: Since the hotel industry is a competitive market, it is bound to have a great deal of rivalry especially in B2B inbound communication because every hotel wants to look different from other hotels, 
and wants to please its clients. In competition, it is important to maintain your customers and see how you can get potential customers [27].

With regard to question 6 in Table I: It is easy for a customer to take patronage elsewhere if they place an order and it takes time for the hotel to respond to them. Customers will stay at hotels that listen to their suggestions and provide what they want. Customers who have businesses will want to monitor their business even if they are out of station and if the hotel does not provide the technology needed they will move to another hotel that is offering better benefits. B2B inbound communication significantly shows that vendors are actively marketing EC to hotels and that there is a great deal of rivalry in the business environment, thus making it necessary for hotels to consider EC.

The Table II below shows the four dependent variables of EC adoption and the strength of the relationship between competition and the extent of EC adoption. Pearsons correlation analysis was employed to examine the association between competition and the extent of EC adoption. The categories show a positive relationship between the extent of adoption of EC and competition and all the four categories are statistically significant at 0.01

TABLE II: CORRELATION ANALYSIS OF COMPETITION OF EC

\begin{tabular}{llc}
\hline & Correlation & Sig. \\
\hline B2C outbound communication & $.538^{* *}$ & .000 \\
\hline B2C order taking & $.421^{* *}$ & .000 \\
\hline B2B inbound communication & $.421^{* *}$ & .000 \\
\hline B2B outbound communication & $.583^{*} *$ & .000 \\
\hline
\end{tabular}

* Correlation is significant at the 0.05 level (2-tailed).

** Correlation is significant at the 0.01 level (2-tailed).

On B2C outbound communication $r$ is 0.538 , B2C order taking is $0.421 \mathrm{~B} 2 \mathrm{~B}$ inbound communication is 0.421 and $\mathrm{B} 2 \mathrm{~B}$ outbound communication is $\mathrm{r}$ is 0.583

TABLE III: MultiPle REgRESSION ANALYSIS ON THE EXTENT OF EC

\begin{tabular}{llllll}
\multicolumn{5}{c}{ ADOPTION } & \\
\hline Equation & RMSE & R-sq. & F & P \\
\hline $\begin{array}{l}\text { B2C } \\
\text { communication }\end{array}$ & outbound & 1.027 & 0.217 & 4.983 & .00 \\
\hline B2C order-taking & & & & \\
\hline B2B inbound communication & 1.167 & .355 & 9.915 & .00 \\
\hline $\begin{array}{l}\text { B2B } \\
\text { communication }\end{array}$ & outbound & 1.234 & .336 & 9.115 & .00 \\
\hline
\end{tabular}

TABLE IV: MULTIPLE REGRESSION COEFFICIENTS

\begin{tabular}{|l|l|l|l|}
\hline & \multicolumn{3}{l|}{} \\
& \multicolumn{2}{|l|}{ Standardised coefficients } & Sig. \\
\hline & Beta & Std. Error & Beta \\
\hline B2C Outbound & $.359^{* *}$ & .050 & .000 \\
B2C Order taking attitude & $.371^{* *}$ & .042 & .000 \\
Information intensity & $.483^{* *}$ & .038 & .000 \\
Competition & $.268^{* *}$ & .052 & .000 \\
Independent variable: competition & & \\
$*$ Correlation is significant at the 0.05 level (2-tailed). \\
** Correlation is significant at the 0.01 level (2-tailed).
\end{tabular}

All the dependent variables have a positive influence on the extent of adoption of EC on competition as shown in Table III. The dependent variable significantly contributed to the model for predicting the extent of adoption of EC on competition prediction. $\mathrm{R}^{2}$ variation is explained by independent variables in the model. In the of $\mathrm{B} 2 \mathrm{C}$ order taking, the value of $\mathrm{R}^{2}$ is 0.44 , which means that $44 \%$ of the variance in the overall extent of adoption of EC on competition is explained by this model.

The beta coefficients give a measure of the contribution of each variable to the model, as shown in Table IV. A large value indicates that a unit change in this predictor variable has a large effect on the independent variable. All the dependent variables have a positive influence on the independent variables

\section{CONCLUSION}

There is a positive association between the extent of EC and adoption as well as multiple regression $p$ which is also significant. The significant level is 0.01 , the hotel industry is a competitive one and there are many rivalries within the industry. Customers switch from one hotel to the next therefore it is important to meet the requirements of the customers. Customers will move to the next hotel depending on what the hotels are offering. The hotels that were surveyed reported that they are receiving pressure from their customers to offer certain services failing which they will move to hotels offering those services. Since the industry is wide there is little customer loyalty, customers just switch from one hotel to the next.

The findings are consistent with [28] stating that EC initiatives may be considered as providing a competitive advantage for managing in competitive environments. The correlation analysis indicates a positive relationship between E-commerce adoption and competition in the hotel industry in South Africa.

\section{REFERENCES}

[1] P. Kotler and G. Amstrong, Principles of Marketing, $10^{\text {th }}$ Ed., New Jersey, USA: Pearon Prentice Hall, 2004.

[2] C. P. Barros and P. U. C. Dieke, "Technical efficiency of African hotels," International Journal of Hospital Management, vol. 27, no. 3, 2008.

[3] N. Kshetri, "Barriers to e-commerce and competitive business models in developing countires: A case study," Electronic Commerce Research and Applications, vol. 6, no. 4, pp. 443-452, 2007.

[4] N. M. Mndzebele, "The use of information and communication tehnologies in South African hotels - A self evaluation by hotel managers," Doctoral dissertation, University of Kwazulu Natal South Africa, 2012.

[5] A. Akbaba, "Measuring service quality in the hotel industry: A study in a business hotel in Turkey," Hospitality Management, pp. 170-192, 2006.

[6] G. Gazzoli, W. G. Kim, and R. Palakurthi, "Online distribution strategies and competition: are the global hotel companies getting it right," International Journal of Contemporary Hospitality Management, vol. 20, no. 4, pp. 375-387, 2008.

[7] M. V. der Merwe and A. Wocke, "An investigation into responsible tourism practices in the South African hotel industry," South African Journal of Business Management, vol. 38, no. 2, pp. 1-15, 2007.

[8] S. Fraser and W. Wresch, "National competitive advantage in ecommerce efforts: A report from five Carribbean nations perspectives," Global Developnent and Technology, vol. 4, no. 1, pp. 27-44, 2005

[9] M. Kartwi, and R. C. MacGregor, "Electronic commerce adoption barriers in small to medium-sized enterprises (SME) in developed and developing countries: A cross-country comparison," Journal of Electronic Commerce in Organizations, vol. 5, no. 3, pp. 5-51, 2007. 
[10] H. F. Lin and S. M. Lin, "Determinants of e-business diffussion," Technovation, vol. 28, no. 3, pp. 135-145, 2008.

[11] A. R. Jahanshani, "Analysing the effects of electronic commerce on organisational performance: Evidence from small and medium enterprises," African Journal of Business management, vol. 5, no. 15, pp. 6486-6496, 2011.

[12] G. M. Rezvani, "Strategic planning: a tool for managing organization in competitive environments," Australian Journal of Basic and Applied Sciences, vol. 5, no. 9, pp. 1537-1546, 2011.

[13] N. Mndzebele, "Atitudes of hotel managers towards EC in South Africa," International Journal of Information and Education Technology, vol. 3, no. 1, pp. 63-66, January, 2013

[14] H. El-Gohary, "Factors affecting e-marketing adoption and implementation in tourism firms: An empirical investigation of Egyptian small tourism organisations," Tourism Management, no. 33, pp. 1256-1269, 2012.

[15] N. Mndzebele, "Information intensity and its effects on EC adoption," International Journal of Advanced Computer Technology, vol. 2, no. 3, pp. 105-108, 2013

[16] S. Khemtong and L. M. Roberts, "Adoption of internet and web technology for hotel marketing: A study of hotels in Thailand," Journal of Business Systems, Governance and Ethics, vol. 1, no. 2, pp. 47-60, 2006.

[17] D. Naranjo-Gil, "The influence of environmental and organisational factors on innovation adoptions: Consequences for performance in public sector organisations," Technovation, vol. 29, pp. 810-818, 2009.

[18] A. Molla and P. Licker, "Maturation stage of e-commerce in developing countries: A survey of South african companies," Journal of IT and International Development, vol. 2, no. 1, pp. 89-98, 2004.

[19] Porter, Competitive Strategy: Techniques for Analysing Industries and Competitors, NewYork: The Free Press, 1980

[20] M. M. Salawani, "E-commerce and value creation: Empirical evidence in Malaysia," presented at the European Applied Business Research Conference, Rothenburg, 2009.
[21] T. Maswera, R. Dawson, and J. Edwards, “ E-commerce adoption of travel and tourism organisations in South Africa, Kenya, Zimbabwe and Uganda," Telematics and Informatics, Elsevier, vol. 26, pp. 12-19, 2006.

[22] TGCSA. (April 20, 2009). Listing of graded hotels by province. [Online]. Available: www.tourismgrading.co.za

[23] P. Leedy and J. E. Ormrod, Practical Research (Planning and Design), New Jersey: Pearson Merrill Prentice Hall, pp. 25-80, 2005

[24] K. L. Kraemer, "Post adoption variations in usage and value of e-business by organisations: cross country evidence from the retail industry," Information Systems Research, vol. 16, no. 1, pp. 61-84, 2005.

[25] C. Liao and T. Hu, "Knowledge transfer and competitive advantage on envirnmental uncertainity: An empirical study of the Taiwan semiconductor industry," Technovation, vol. 27, pp. 402-411, 2007.

[26] J. Murphy, R. Schegg, and D. Olaru, "Investigating the evolution of hotel internet adoption," Information Technology \& Tourism, vol. 8, pp. 161-177, 2006.

[27] D. Pare, "B2B e-commerce services and developing countries: Disentagling myth from reality," in Proc. Association of Internet researchers (AoIR) International Conference on Internet Research, Maastricht: The London School of Economics \& Political Science, 2002, pp. 1-13.

[28] T. Maswera, J. Edwards, and R. Dawson, "Recommendations for e-commerce systems in the tourism industry of Sub-Saharan Africa," Telematics and Informatics, vol. 26, pp. 12-19, 2009.

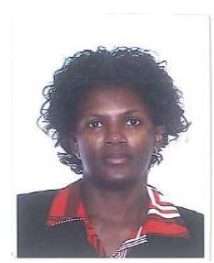

N. Mndzebele received her bachelor of accounting in 1989 from University of Swaziland in 1995. And she got an MBA in Cal Poly in California USA and PhD in information systems in UKZN South Africa 2012. She has been teaching since 1992 . 